\title{
OPTIMASI JUMLAH PRODUKSI BAJA TULANGAN DENGAN METODE LINEAR PROGRAMMING
}

\author{
Kenny $^{1}$ dan Iwan B. Santoso ${ }^{2}$ \\ ${ }^{1}$ Program Studi Sarjana Teknik Sipil, Universitas Tarumanagara, Jl. Letjen S Parman No.1 Jakarta \\ Email: kenny_it7a@yahoo.com \\ ${ }^{2}$ Program Studi Sarjana Teknik Sipil, Universitas Tarumanagara, Jl. Letjen S Parman No.1 Jakarta \\ Email:iwsantoso@hotmail.com
}

\begin{abstract}
ABSTRAK
Kegiatan dalam proses produksi tidak terlepas dari perencanaan produksi. PT Jakarta Cakratunggal Steel Mills adalah salah satu perusahaan yang turut berperan dalam penyediaan baja tulangan. Proses produksi baja tulangan ini wajib melalui beberapa tahapan dan harus memenuhi Standar Nasional Indonesia (SNI). Optimasi perencanaan produksi membutuhkan pola permintaan yang tepat dan disertai dengan kendala - kendala untuk dapat menghasilkan baja tulangan yang berkualitas baik, sesuai target perusahaan dengan biaya produksi yang minimum. Sebelum menganalisa perencanaan produksi ini, peramalan deret waktu dihitung dengan metode peramalan dekomposisi multiplikatif sebagai dasar penentuan jumlah permintaan di masa yang akan datang. Metode yang digunakan untuk penelitian ini adalah pemrograman linier karena dapat melakukan perhitungan iterasi secara cepat dan tepat sehingga perencanaan produksi dapat terselesaikan dengan mudah. Pemrograman linier dapat menganalisis berbagai kendala yang terkait dengan situasi kehidupan nyata di perusahaan dan memberikan solusi terbaik meskipun dalam kondisi seperti itu. Penelitian ini menggunakan 18 jenis tulangan yang diproduksi untuk dilakukan perencanaan selama 1 tahun ke depan. Kendala - kendala yang berpengaruh dalam optimasi produksi ini adalah jumlah permintaan, persediaan efektif, jam kerja reguler dan lembur, kapasitas jumlah produksi, kecepatan produksi dan ketersediaan baja tulangan di gudang. Dengan menggunakan metode ini didapatkan total biaya perencanaan produksi selama 1 tahun yaitu jika menggunakan 3 shift membutuhkan biaya sebesar Rp 1.301.490.788.783,-; untuk skenario 1 dengan 2 shift sebesar Rp 1.302.327.073.616,- dan untuk skenario 2 dengan 2 shift jam lembur terbatas, produksi tidak dapat memenuhi permintaan perusahaan. Perbedaan ini sebagai akibat dari pengaruh total jam kerja dan kecepatan produksi setiap jenis ukuran tulangan.
\end{abstract}

Kata kunci: Baja Tulangan, Perencanaan, Produksi, Metode Pemrograman Linier

\section{PENDAHULUAN}

\section{Latar Belakang}

Masalah produksi adalah masalah yang rumit dan sangat perlu diperhatikan oleh setiap perusahaan karena membutuhkan koordinasi yang baik dari setiap elemen perusahaan. Kelancaran produksi di dalam suatu perusahaan tergantung pada perencanaan seberapa banyak barang yang perlu dihasilkan, bahan material mentah yang digunakan, dan sumber daya manusia yang turut berperan dalam kegiatan proses produksi dari awal sampai barang jadi (Hutajulu, 2010). Untuk itu diperlukan perhatian khusus dalam setiap proses produksi dan pengendalian dari kontrol produksi itu sendiri sehingga tidak menghasilkan stok barang yang berlebihan.

Sektor industri yang akan dibahas disini adalah tentang industri baja karena sektor ini sangat berpengaruh terhadap perkembangan manufaktur yang nyata. Baja merupakan salah satu komponen utama untuk keperluan pembangunan dalam negeri, seperti gedung bertingkat, mesin pabrik, otomotif dan lain - lain.

Proses aliran produksi perusahaan besi dan baja memiliki suatu fitur teknis yaitu multi link dan proses yang sangat rumit dalam pembuatannya karena meliputi prosedur dari kerja sebelum pembuatan sampai dengan proses jadi yang saling berhubungan erat. Faktor kendala dalam proses produksi ini sangat bergantung pada jenis bahan baku yang digunakan, produk setengah jadi dan produk akhir yang terlihat dari hasil produksi. Dari penelitian yang telah dilakukan (Shao, et al., 2007) dalam makalahnya yang berjudul Theory and Method of Production Logistics Plan Optimizing for an Iron and Steel, dapat diketahui bahwa proses logistik dari produksi ini memiliki beberapa masalah yang berkaitan dengan tingkat pelaksanaan yang rendah, kapasitas penyimpanan dan lain - lain. Sebagai basis inti dari manajemen logistik produksi, rencana logistik dari produksi memiliki arti penting dalam meningkatkan kemampuan manajemen logistik perusahaan tersebut. 
Berdasarkan bagan pembagian konsumsi baja menurut Indonesian Iron and Steel Industry Association (2017) yang dapat dilihat pada gambar 1, mayoritas konsumsi baja di Indonesia adalah di bidang konstruksi dengan nilai 78\%, kemudian diikuti oleh sektor otomotif yang berkisar $8 \%$ dan untuk sektor minyak dan gas berada pada posisi yang ketiga sebesar $7 \%$ dan untuk kegunaan lainnya juga sebesar $7 \%$.

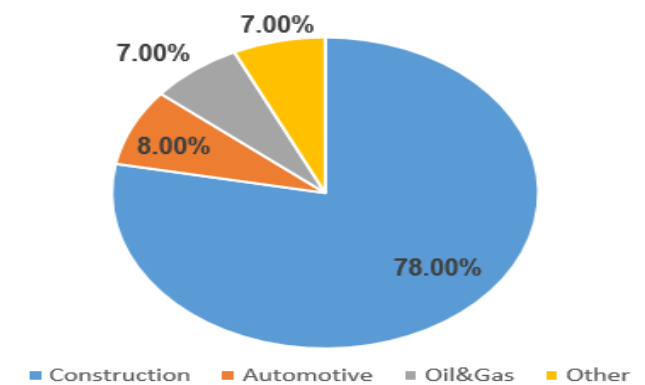

Gambar 1. Pembagian Konsumsi Baja di Indonesia

Metode linear programming adalah metode perhitungan matematika yang tepat untuk memecahkan permasalahan yang rumit ini karena dapat berfungsi sebagai alat pengambilan keputusan yang membantu perusahaan untuk mengkombinasikan variasi produk yang ada berdasarkan keterbatasan sumber daya yang dimiliki perusahaan. Dengan demikian, penggunaan metode ini diharapkan agar perusahaan dapat menghasilkan jumlah produksi yang tepat sehingga dapat memenuhi permintaan pasar dan menciptakan nilai pelanggan.

\section{Identifikasi Masalah}

Berdasarkan pembahasan pada bagian sebelumnya, masalah yang akan dijadikan bahan penelitian yaitu biaya produksi baja tulangan yang sangat mahal sebagai pengaruh dari faktor - faktor kendala di dalam sebuah perusahaan.

\section{Rumusan Masalah}

Sebagai upaya melakukan optimasi untuk produksi baja tulangan maka masalah yang ingin dipecahkan adalah bagaimana perencanaan produksi baja tulangan yang tepat agar dapat mencapai target produksi dengan biaya yang minimum.

\section{Tujuan Penelitian}

1. Membuat pemodelan linear programming agar dapat mengkaji perencanaan produksi baja tulangan yang tepat sehingga target produksi dapat tercapai.

2. Menganalisis hasil optimasi produksi baja tulangan.

\section{Batasan Penelitian}

1. Metode perhitungan yang digunakan adalah linear programming.

2. Permasalahan mengenai produksi baja yang digunakan terbatas pada baja tulangan.

3. Semua data yang didapat untuk penelitian berasal dari perusahaan pabrik baja PT Jakarta Cakratunggal Steel Mills yang berlokasi di Jakarta Timur.

\section{TINJAUAN PUSTAKA}

\section{Produksi}

Menurut Gaspersz (2004), produksi merupakan fungsi pokok dalam setiap organisasi, yang mencakup aktivitas yang bertanggung jawab untuk menciptakan nilai tambah produk yang merupakan output dari setiap organisasi industri ini.

\section{Baja Tulangan}

Baja tulangan (besi beton) adalah baja yang digunakan untuk penulangan konstruksi beton atau lebih dikenal dengan beton bertulang. Baja tulangan ini memiliki bentuk seperti batang pernampang lingkaran yang diproduksi dari bahan baku billet dengan cara hot rolling. Berdasarkan bentuknya, baja tulangan beton ini dapat dibedakan menjadi dua 
jenis yaitu baja tulangan beton polos dan baja tulangan beton sirip (tulangan ulir) (Badan Standarisasi Nasional, 2014).

\section{Peramalan}

Menurut Gaspersz (2004), aktivitas peramalan adalah suatu fungsi bisnis yang berusaha memperkirakan permintaan dan penggunaan produk sehingga produk - produk itu dapat dibuat dalam kuantitas yang tepat. Jadi peramalan disini merupakan suatu taksiran yang ilmiah yang dilakukan dengan melibatkan data masa lalu dan menempatkannya ke masa yang akan datang dengan suatu bentuk model matematis meskipun akan terdapat sedikit kesalahan yang disebabkan oleh adanya keterbatasan kemampuan manusia.

\section{Metode Peramalan Deret Waktu (Time-Series)}

Menurut Prasetya dan Lukiastuti (2009) time-series didasarkan pada waktu yang berurutan atau yang berjarak sama (mingguan, bulanan, kuartalan, dan lainnya). Analisis runtun waktu mencoba untuk meramalkan kejadian - kejadian di waktu yang akan datang atas dasar serangkaian data di masa lalu.

\section{Metode Trend}

Menurut Sharma (2007), trend adalah sebuah arah umum jangka panjang (keatas, kebawah atau konstan) dari sebuah iklim bisnis dalam suatu periode beberapa tahun. Proyeksi dari sebuah metode tren cocok dengan sebuah garis tren dari deret urutan waktu dan proyek - proyek peramalan jangka menengah hingga panjang.

\section{Metode Pemulusan Eksponensial (Exponential Smoothing)}

Menurut Prasetya dan Lukiastuti (2009), metode ini adalah suatu tipe teknik peramalan rata - rata bergerak yang melakukan penimbangan terhadap data masa lalu dengan cara eksponensial sehingga data paling akhir mempunyai bobot atau timbangan lebih besar dalam rata - rata bergerak. Dengan exponential smoothing sederhana, forecast dilakukan dengan cara ramalan periode terakhir ditambah porsi perbedaan (disebut $\alpha$ ) antara permintaan nyata periode terakhir dan ramalan periode terakhir.

\section{Metode Dekomposisi}

Menurut Herjanto (2008), metode ini mengidentifikasi tiga komponen pola dasar yang terdapat dalam suatu serial data, yaitu trend, musiman dan siklus, dan menggunakannya untuk peramalan. Faktor trend, yang mewakili perilaku dalam jangka panjang, dapat berupa garis lurus yang menaik, menurun atau mendatar, atau dalam beberapa situasi tertentu dapat berupa garis eksponensial atau bentuk lain. Faktor musiman berkaitan dengan fluktuasi berkala dengan panjang yang konstan dan kedalaman yang proporsional, yang dapat disebabkan oleh faktor cuaca, musim liburan, hari gajian dan sebagainya. Faktor siklus mewakili kemajuan atau kemunduran yang disebabkan oleh kondisi perekonomian atau kondisi industri tertentu, misalnya resesi, normal, atau booming.

\section{Penentuan Kesalahan Peramalan}

Menurut Coyle, et al. (2009), beberapa peramalan tidak mungkin sepenuhnya benar karena peramalan yang lebih tinggi dari permintaan dan beberapa mungkin lebih rendah. Kunci untuk menghasilkan peramalan yang baik adalah dengan memilih teknik yang menyediakan nilai kesalahan peramalan terkecil.

\section{Cumulative Sum of Forecast Errors (CFE)}

CFE menghitung nilai total kesalahan peramalan dari sejumlah data dengan mempertimbangkan kesalahan negatif dan positifnya. Bagaimanapun jika mempertimbangkan kedua kesalahan ini, maka metode ini bisa menghasilkan kesalahan yang rendah secara keseluruhan, walaupun perkiraan periode individual bisa lebih tinggi atau lebih rendah daripada permintaan sebenarnya.

2. Mean Squared Error (MSE)

MSE merupakan rata-rata selisih kuadrat antara nilai yang diramalkan dan yang diamati. Keuntungan penggunaan MSE adalah bahwa ia cenderung menonjolkan deviasi yang besar karena adanya pengkuadratan.

\section{Mean Absolute Deviation (MAD)}

MAD merupakan ukuran kesalahan peramalan keseluruhan untuk sebuah model. Nilai ini dihitung dengan mengambil jumlah nilai absolut dari tiap kesalahan peramalan dibagi dengan jumlah periode data $n$.

\section{Mean Absolute Percentage Error (MAPE)}

MAPE berkaitan dengan munculnya permasalahan dengan MAD dan MSE yang nilainya bergantung pada besarnya jumlah barang yang diramal. Nilai ini dihitung dengan mengambil jumlah nilai absolut antara kesalahan peramalan 
pada periode t dibagi dengan permintaan sebenarnya pada periode t. Selanjutnya akan dibagi dengan jumlah periode data $\mathrm{n}$ dan dikali dengan $100 \%$.

\section{Pemrograman Linier}

Pemrograman linier merupakan sebuah teknik optimasi yang dapat memaksimumkan atau meminimumkan nilai sebuah fungsi berdasarkan kondisi - kondisi tertentu dan teknik ini hanya membutuhkan jumlah langkah yang terbatas (Chatterjee, 2005).

Menurut Chatterjee (2005), secara umum bentuk umum model program linier dapat digambarkan sebagai berikut :

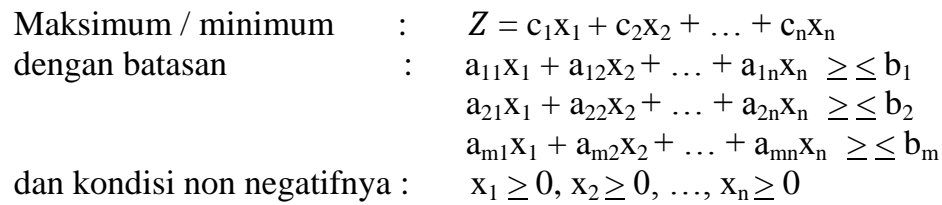

Keterangan :

1. Variabel $\mathrm{x}_{1}, \mathrm{x}_{2}, \ldots, \mathrm{x}_{\mathrm{n}}$ adalah variabel keputusan (decision variable) atau variabel input.

2. Konstanta $c_{1}, c_{2}, \ldots, c_{n}$ adalah koefisien biaya atau koefisien harga.

3. Konstanta $b_{1}, b_{2}, \ldots, b_{m}$ adalah parameter - parameter atau batasan yang disyaratkan.

4. Konstanta $\mathrm{a}_{\mathrm{ij}}, \mathrm{i}=1,2, \ldots, \mathrm{m} ; \mathrm{j}=1,2, \ldots, \mathrm{n}$ adalah koefisien struktural.

\section{METODOLOGI PENELITIAN}

\section{Tahapan - Tahapan Penelitian}

Pada penelitian ini dilakukan tahapan penelitian dengan langkah - langkah sebagai berikut :

1. Melakukan identifikasi awal mengenai permasalahan yang ingin dibahas.

2. Membaca beberapa literatur dan bahan pustaka lainnya yang berguna sebagai bahan referensi atau informasi tambahan.

3. Membuat perumusan masalah berdasarkan identifikasi pada awal penelitian dan tujuan yang ingin dicapai dari penelitian yang akan dilakukan.

4. Mencari data yang dibutuhkan dengan melakukan survei ke perusahaan secara langsung dan melakukan wawancara dengan pihak perusahaan mengenai data apa saja yang dibutuhkan untuk keperluan penelitian.

5. Melakukan pemeriksaan kembali apakah data yang dikumpulkan sudah cukup lengkap untuk proses penelitian.

6. Melakukan pengolahan data dengan menerapkan metode peramalan terlebih dahulu dan dilanjutkan menggunakan metode linear programming.

7. Melakukan analisis data hasil perhitungan yang didapat dari program Lingo.

8. Menarik kesimpulan dan saran berdasarkan hasil analisis data.

Seluruh langkah kerja yang akan dilakukan dalam penelitian ini dapat dilihat melalui alur penelitian yang dapat dilihat melalui gambar 2 .

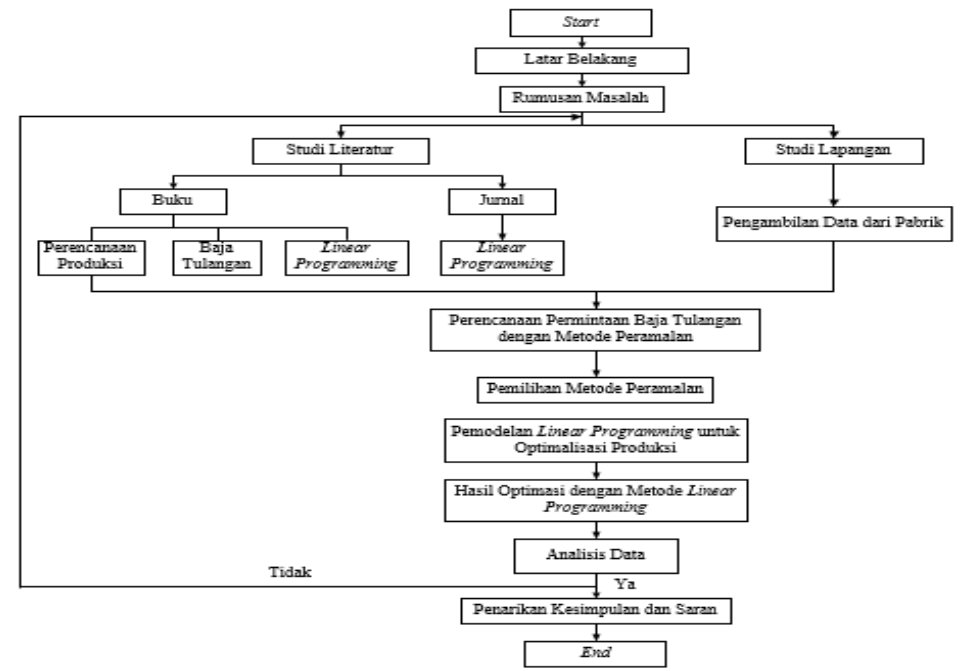

Gambar 2. Alur Penelitian 


\section{HASIL DAN PEMBAHASAN}

\section{Pengumpulan Data}

Berdasarkan pengumpulan data yang telah dilakukan, didapatkan data permintaan 18 jenis baja tulangan yang dilakukan peramalan dan diterapkan dalam pemodelan linear programming. Hal yang harus dilakukan adalah pengambilan data permintaan salah satu jenis tulangan dan pemilihan metode peramalan berdasarkan nilai kesalahan terkecil (MSE) yang dapat dilihat pada tabel 1 dan tabel 2. Berdasarkan penerapan metode peramalan, maka metode peramalan yang dipilih adalah multiplicative decomposition.

Tabel 1. Data Permintaan Baja Tulangan TS 40 Diameter 10

\begin{tabular}{|c|c|}
\hline Bulan & Permintaan (Ton) \\
\hline Mei 2017 & $3.005,6284$ \\
\hline Juni 2017 & $1.281,4136$ \\
\hline Juli 2017 & $1.709,1632$ \\
\hline Agustus 2017 & $2.643,7388$ \\
\hline September 2017 & $2.158,136$ \\
\hline Oktober 2017 & $2.909,4654$ \\
\hline November 2017 & $1.922,0538$ \\
\hline Desember 2017 & $1.202,5148$ \\
\hline Januari 2018 & $1.237,0876$ \\
\hline Februari 2018 & 930,4464 \\
\hline Maret 2018 & $1.226,7202$ \\
\hline April 2018 & $1.250,1486$ \\
\hline
\end{tabular}

Tabel 2. Nilai Akurasi Kesalahan dari Setiap Metode Peramalan

\begin{tabular}{|c|c|c|c|}
\hline No & $\begin{array}{c}\text { Metode } \\
\text { Peramalan }\end{array}$ & MSE & Urutan \\
\hline 1 & Trend & $299.405,1$ & 3 \\
\hline 2 & $\begin{array}{c}\text { Exponential } \\
\text { Smoothing }\end{array}$ & $553.764,8$ & 4 \\
\hline 3 & $\begin{array}{c}\text { Multiplicative } \\
\text { Decomposition }\end{array}$ & 137.567 & 1 \\
\hline 4 & $\begin{array}{c}\text { Additive } \\
\text { Decomposition }\end{array}$ & $146.678,8$ & 2 \\
\hline
\end{tabular}

\section{Pemodelan Linear Programming}

\section{Decision Variable}

A. $A_{t}-R_{t}$ : jumlah baja tulangan yang diproduksi pada bulan $t$

B. $\mathrm{UA}_{\mathrm{t}}-\mathrm{UR}_{\mathrm{t}}$ : jumlah persediaan baja tulangan pada bulan $\mathrm{t}$

C. $T_{t}$ : jumlah jam tenaga kerja reguler yang digunakan pada bulan $t$

D. $\mathrm{V}_{\mathrm{t}}$ : jumlah jam tenaga kerja lembur yang digunakan pada bulan $\mathrm{t}$

E. $S_{t}$ : jumlah jam menganggur pada bulan $t$

Keterangan :

1. A = tulangan polos diameter $12 \mathrm{TP} 24$ dengan panjang 12 meter.

2. $\mathrm{B}=$ tulangan ulir diameter $10 \mathrm{TS} 40$ dengan panjang 12 meter.

3. $\mathrm{C}=$ tulangan ulir diameter $13 \mathrm{TS} 40$ dengan panjang 12 meter.

4. $\mathrm{D}=$ tulangan ulir diameter 16 TS 40 dengan panjang 12 meter.

5. $\mathrm{E}=$ tulangan ulir diameter $19 \mathrm{TS} 40$ dengan panjang 12 meter.

6. $\mathrm{F}=$ tulangan ulir diameter $22 \mathrm{TS} 40$ dengan panjang 12 meter.

7. $\mathrm{G}=$ tulangan ulir diameter $25 \mathrm{TS} 40$ dengan panjang 12 meter.

8. $\mathrm{H}=$ tulangan ulir diameter 29 TS 40 dengan panjang 12 meter.

9. $\mathrm{I}=$ tulangan ulir diameter $32 \mathrm{TS} 40$ dengan panjang 12 meter. 
10. $\mathrm{J}=$ tulangan ulir diameter $40 \mathrm{TS} 40$ dengan panjang 12 meter.

$11 . \mathrm{K}=$ tulangan ulir diameter $10 \mathrm{TS} 50$ dengan panjang 12 meter.

12. $\mathrm{L}=$ tulangan ulir diameter $13 \mathrm{TS} 50$ dengan panjang 12 meter.

13. $\mathrm{M}=$ tulangan ulir diameter 16 TS 50 dengan panjang 12 meter.

14. $\mathrm{N}=$ tulangan ulir diameter 19 TS 50 dengan panjang 12 meter.

$15 . \mathrm{O}=$ tulangan ulir diameter $22 \mathrm{TS} 50$ dengan panjang 12 meter.

16. $\mathrm{P}=$ tulangan ulir diameter 25 TS 50 dengan panjang 12 meter.

17. $\mathrm{Q}=$ tulangan ulir diameter 29 TS 50 dengan panjang 12 meter.

18. $\mathrm{R}=$ tulangan ulir diameter 32 TS 50 dengan panjang 12 meter.

19. $\mathrm{t}=$ bulan $1,2,3, \ldots, 12$.

\section{Objective Function}

A. Biaya Produksi

Biaya produksi adalah biaya tetap yang digunakan untuk memproduksi baja tulangan dengan perhitungan harga jual per batang (12 meter) dikurangi dengan besarnya keuntungan yang telah ditetapkan perusahaan dan dapat dilihat pada tabel 3 di bawah ini.

Tabel 3. Biaya Produksi Baja Tulangan

\begin{tabular}{|c|c|c|c|c|c|c|}
\hline No & Jenis & Diameter $(\mathrm{mm})$ & Panjang (m) & Berat $(\mathrm{kg})$ & Berat per $\mathrm{m}^{\prime}(\mathrm{kg})$ & Harga per batang $(\mathrm{Rp})$ \\
\hline 1 & Polos TP24 & 12 & 12 & 10,66 & 0,89 & 81.200 \\
\hline 2 & Ulir TS40 & 10 & 12 & 7,4 & 0,62 & 56.000 \\
\hline 3 & Ulir TS40 & 13 & 12 & 12,48 & 1,04 & 94.800 \\
\hline 4 & Ulir TS40 & 16 & 12 & 18,96 & 1,58 & 144.800 \\
\hline 5 & Ulir TS40 & 19 & 12 & 26,76 & 2,23 & 209.600 \\
\hline 6 & Ulir TS40 & 22 & 12 & 35,76 & 2.98 & 272.000 \\
\hline 7 & Ulir TS40 & 25 & 12 & 46,20 & 3,85 & 353.200 \\
\hline 8 & Ulir TS40 & 29 & 12 & 62,28 & 5,19 & 440.000 \\
\hline 9 & Ulir TS40 & 32 & 12 & 75,72 & 6,31 & 574.800 \\
\hline 10 & Ulir TS40 & 40 & 12 & 118,44 & 9,86 & 772.000 \\
\hline 11 & Ulir TS 50 & 10 & 12 & 7,4 & 0,62 & 68.000 \\
\hline 12 & Ulir TS 50 & 13 & 12 & 12,48 & 1,04 & 106.800 \\
\hline 13 & Ulir TS 50 & 16 & 12 & 18,96 & 1,58 & 164.000 \\
\hline 14 & Ulir TS 50 & 19 & 12 & 26,76 & 2,23 & 230.400 \\
\hline 15 & Ulir TS 50 & 22 & 12 & 35,76 & 2,98 & 296.000 \\
\hline 16 & Ulir TS 50 & 25 & 12 & 46,20 & 3,85 & 377.600 \\
\hline 17 & Ulir TS 50 & 29 & 12 & 62,28 & 5,19 & 468.000 \\
\hline 18 & Ulir TS 50 & 32 & 12 & 75,72 & 6,31 & 600.000 \\
\hline
\end{tabular}

\section{B. Biaya Jam Tenaga Kerja Reguler}

Biaya tenaga kerja disini berhubungan langsung dengan biaya produksi yaitu sebesar Rp 33.000 / jam dengan jam kerja reguler 7 jam / hari.

C. Biaya Penyimpanan

Biaya yang timbul akibat adanya penyimpanan barang di gudang yaitu sebesar Rp 6.000 / ton.

D. Biaya Jam Tenaga Kerja Lembur

Biaya tenaga kerja lembur pada proses produksi baja tulangan ini yaitu sebesar Rp 49.500 / jam.

Perumusan model fungsi tujuan :

Min Z : $\left.\left[\left(\left(\mathrm{A}_{1-12} / 0,01066\right) \times 81.200\right)+\left(\mathrm{B}_{1-12} / 0,0074\right) \times 56.000\right)+\left(\mathrm{C}_{1-12} / 0,01248\right) \times 94.800\right)+\left(\mathrm{D}_{1-12} / 0,01896\right) \times$ $\left.\left.\left.144.800)+\left(\mathrm{E}_{1-12} / 0,02676\right) \times 209.600\right)+\left(\mathrm{F}_{1-12} / 0,03576\right) \times 272.000\right)+\left(\mathrm{G}_{1-12} / 0,0462\right) \times 353.200\right)+\left(\mathrm{H}_{1-12} / 0,06228\right) \times$ $\left.\left.\left.440.000)+\left(\mathrm{I}_{1-12} / 0,07572\right) \times 574.800\right)+\left(\mathrm{J}_{1-12} / 0,11844\right) \times 772.000\right)+\left(\mathrm{K}_{1-12} / 0,0074\right) \times 68.000\right)+\left(\mathrm{L}_{1-12} / 0,01248\right) \times$ $\left.\left.\left.106.800)+\left(\mathrm{M}_{1-12} / 0,01896\right) \times 164.000\right)+\left(\mathrm{N}_{1-12} / 0,02676\right) \times 230.400\right)+\left(\mathrm{O}_{1-12} / 0,03576\right) \times 296.000\right)+\left(\mathrm{P}_{1-12} / 0,0462\right) \times$ $\left.\left.377.600)+\left(\mathrm{Q}_{1-12} / 0,06228\right) \times 468.000\right)+\left(\mathrm{R}_{1-12} / 0,07572\right) \times 600.000\right)+\left(33.000 \mathrm{~T}_{1}+33.000 \mathrm{~T}_{2}+33.000 \mathrm{~T}_{3}+33.000\right.$ $\left.\mathrm{T}_{4}+33.000 \mathrm{~T}_{5}+33.000 \mathrm{~T}_{6}+33.000 \mathrm{~T}_{7}+33.000 \mathrm{~T}_{8}+33.000 \mathrm{~T}_{9}+33.000 \mathrm{~T}_{10}+33.000 \mathrm{~T}_{11}+33.000 \mathrm{~T}_{12}\right)+(6.000$ $\mathrm{UA}_{1-12}+6.000 \mathrm{UB}_{1-12}+6.000 \mathrm{UC}_{1-12}+6.000 \mathrm{UD}_{1-12}+6.000 \mathrm{UE}_{1-12}+6.000 \mathrm{UF}_{1-12}+6.000 \mathrm{UG}_{1-12}+6.000 \mathrm{UH}_{1-12}+$ $6.000 \mathrm{UI}_{1-12}+6.000 \mathrm{UJ}_{1-12}+6.000 \mathrm{UK}_{1-12}+6.000 \mathrm{UL}_{1-12}+6.000 \mathrm{UM}_{1-12}+6.000 \mathrm{UN}_{1-12}+6.000 \mathrm{UO}_{1-12}+6.000$ $\left.\mathrm{UP}_{1-12}+6.000 \mathrm{UQ}_{1-12}+6.000 \mathrm{UR}_{1-12}\right)+\left(49.500 \mathrm{~V}_{1}+49.500 \mathrm{~V}_{2}+49.500 \mathrm{~V}_{3}+49.500 \mathrm{~V}_{4}+49.500 \mathrm{~V}_{5}+49.500 \mathrm{~V}_{6}+\right.$ $\left.\left.\left.49.500 \mathrm{~V}_{7}+49.500 \mathrm{~V}_{8}+49.500 \mathrm{~V}_{9}+49.500 \mathrm{~V}_{10}+49.500 \mathrm{~V}_{11}+49.500 \mathrm{~V}_{12}\right)\right)\right]$. 


\section{Constraints}

A. Kendala Kapasitas Gudang

Pabrik ini mempunyai 2 buah gudang dengan masing - masing kapasitas gudang sebesar 35.000 ton. Contoh penulisan dalam bentuk persamaan matematis :

$$
\begin{aligned}
& \text { 1. UA1 + UB1 + UC1 + UD1 + UE1 + UF1 + UG1 + UH1 + UI1 + UJ1 + UK1 + UL1 + UM1 + UN1 + UO1 + } \\
& \mathrm{UP} 1+\mathrm{UQ} 1+\mathrm{UR} 1 \leq 70.000
\end{aligned}
$$

B. Kendala Jumlah Permintaan

Jumlah produksi baja tulangan berdasarkan data permintaan yang sudah diterapkan metode peramalan. Penulisan dalam bentuk persamaan :

$$
Y_{t}=A_{t}-R_{t}+\left(U A-R_{t-1}-U A-R_{t}\right)
$$

Keterangan : $\mathrm{Y}_{\mathrm{t}} \quad$ : jumlah permintaan baja tulangan pada periode $\mathrm{t}$

$A_{t}-R_{t}$ : jumlah produksi baja tulangan pada periode $t$

UA-R $\mathrm{R}_{\mathrm{t}-1}$ : jumlah persediaan baja tulangan pada periode $\mathrm{t}$

UA- $R_{t}$ : jumlah persediaan baja tulangan pada periode sebelumnya

Contoh penulisan dalam bentuk persamaan matematis :

1. $\mathrm{A}_{1}+\left(\mathrm{UA}_{0}-\mathrm{UA}_{1}\right)=49,03302$

C. Kendala Tingkat Persediaan

Jumlah persediaan efektif di tempat penyimpanan adalah minimal 30\% dari pemintaan dan maksimal 150 ton. Penulisan dalam bentuk persamaan :

$\mathrm{UA}-\mathrm{R}_{\mathrm{t}} \geq 30 \% * \mathrm{Y}_{\mathrm{t}}$

$\mathrm{UA}-\mathrm{R}_{\mathrm{t}} \geq 150$

Contoh penulisan dalam bentuk persamaan matematis :

1. $\mathrm{A}_{1} \geq 14,70991$

D. Kendala kapasitas jam kerja reguler

Perbedaan jam kerja diakibatkan oleh adanya kebijakan perusahaan yang menetapkan hari libur biasa dan nasional. Penulisan dalam bentuk persamaan: $\quad \mathrm{T}_{\mathrm{t}}+\mathrm{S}_{\mathrm{t}}=\mathrm{W}_{\mathrm{t}}$

Keterangan: $S_{t}$ : waktu menganggur pada periode $t$

$\mathrm{W}_{\mathrm{t}}$ : jam kerja reguler sebenarnya pada periode $\mathrm{t}$

Contoh penulisan dalam bentuk persamaan matematis :

$$
\begin{aligned}
& \text { 1. } \mathrm{T}_{1}=\mathrm{TA}_{1}+\mathrm{TB}_{1}+\mathrm{TC}_{1}+\mathrm{TD}_{1}+\mathrm{TE}_{1}+\mathrm{TF}_{1}+\mathrm{TG}_{1}+\mathrm{TH}_{1}+\mathrm{TI}_{1}+\mathrm{TJ}_{1}+\mathrm{TK}_{1}+\mathrm{TL}_{1}+\mathrm{TM}_{1}+\mathrm{TN}_{1}+\mathrm{TO}_{1}+\mathrm{TP}_{1}+ \\
& \mathrm{TQ}_{1}+\mathrm{TR}_{1} \\
& \text { 2. } \mathrm{S}_{1}=\mathrm{SA}_{1}+\mathrm{SB}_{1}+\mathrm{SC}_{1}+\mathrm{SD}_{1}+\mathrm{SE}_{1}+\mathrm{SF}_{1}+\mathrm{SG}_{1}+\mathrm{SH}_{1}+\mathrm{SI}_{1}+\mathrm{SJ}_{1}+\mathrm{SK}_{1}+\mathrm{SL}_{1}+\mathrm{SM}_{1}+\mathrm{SN}_{1}+\mathrm{SO}_{1}+\mathrm{SP}_{1}+ \\
& \mathrm{SQ}_{1}+\mathrm{SR}_{1} \\
& \text { 3. } \mathrm{T}_{1}+\mathrm{S}_{1}=441
\end{aligned}
$$

E. Kendala Pemakaian Jam Kerja Reguler

Jam kerja nyata yang sesungguhnya dipakai dalam melakukan proses produksi sesuai dengan target pada periode tersebut. Penulisan dalam bentuk persamaan: $\quad T_{t}: x Y_{t}+S_{t}-V_{t}$

$$
Y_{t}: A_{t}-R_{t}+\left(U A-R_{t-1}-U A-R_{t}\right)
$$

sehingga: $T_{t}: x A_{t}-R_{t}-x U A-R_{t-1}+x U A-R_{t}+S_{t}-V_{t}$

$$
\mathrm{xA}_{\mathrm{t}}-\mathrm{R}_{\mathrm{t}}: \mathrm{T}_{\mathrm{t}}+\mathrm{xUA}-\mathrm{R}_{\mathrm{t}-1}-\mathrm{xU} \mathrm{A}_{\mathrm{t}}-\mathrm{R}_{\mathrm{t}}+\mathrm{V}_{\mathrm{t}}-\mathrm{S}_{\mathrm{t}}
$$

Keterangan : $\mathrm{x}$ adalah kecepatan produksi tergantung dari jenis baja tulangan

Contoh penulisan dalam bentuk persamaan matematis :

1. $\mathrm{TA}_{1}+0,0248 \mathrm{UA}_{0}-0,0248 \mathrm{UA}_{1}+\mathrm{VA}_{1}-\mathrm{SA}_{1}=1,216$

F. Kendala Jam Kerja Lembur

Jam kerja yang dipakai untuk memproduksi suatu barang di luar jam kerja reguler. Penulisan dalam bentuk persamaan :

$$
\begin{aligned}
& \mathrm{V}_{\mathrm{t}}-\mathrm{S}_{\mathrm{t}} \leq \mathrm{z} \cdot \mathrm{T}_{\mathrm{t}} \\
& \mathrm{V}_{\mathrm{t}}-\mathrm{S}_{\mathrm{t}} \leq \mathrm{z}\left(\mathrm{xY_{ \textrm {t } }}-\mathrm{xUA}-\mathrm{R}_{\mathrm{t}-1}+\mathrm{xUA}-\mathrm{R}_{\mathrm{t}}+\mathrm{S}_{\mathrm{t}}-\mathrm{V}_{\mathrm{t}}\right) \\
& \mathrm{V}_{\mathrm{t}}-\mathrm{S}_{\mathrm{t}} \leq \mathrm{zxY} \mathrm{T}_{\mathrm{t}}-\mathrm{zxUA}-\mathrm{R}_{\mathrm{t}-1}+\mathrm{zxUA}_{\mathrm{t}} \mathrm{R}_{\mathrm{t}}+\mathrm{zS}_{\mathrm{t}}-\mathrm{zV}_{\mathrm{t}} \\
& \mathrm{V}_{\mathrm{t}}-\mathrm{S}_{\mathrm{t}}+\mathrm{zxUA}-\mathrm{R}_{\mathrm{t}-1}-\mathrm{zxUA} \mathrm{R}_{\mathrm{t}}-\mathrm{zS}_{\mathrm{t}}+\mathrm{zV}_{\mathrm{t}} \leq \mathrm{zxY} \mathrm{Y}_{\mathrm{t}} \\
& (1+\mathrm{z}) \mathrm{V}_{\mathrm{t}}-(1+\mathrm{z}) \mathrm{St}+\mathrm{zxUA}-\mathrm{R}_{\mathrm{t}-1}-\mathrm{zxUA}-\mathrm{R}_{\mathrm{t}} \leq \mathrm{zx} \mathrm{Y}_{\mathrm{t}}
\end{aligned}
$$

Keterangan : $\mathrm{z}$ adalah nilai perbandingan jam kerja reguler dengan jam kerja lembur.

Contoh penulisan dalam bentuk persamaan matematis :

$$
\begin{aligned}
& \text { 1. } V_{1}=V_{1}+V_{1}+V_{1}+V_{1}+V_{1}+V_{1}+V_{1}+V_{1}+V_{1}+V_{1}+V_{1}+V_{1}+V_{1}+V_{1}+V_{1}+ \\
& V_{1}+V_{1}+V_{1} \\
& \text { 2. } 1,0714 \mathrm{VA}_{1}-1,0714 \mathrm{SA}_{1}+0,00177072 \mathrm{UA}_{0}-0,00177072 \mathrm{UA}_{1} \leq 0,08682
\end{aligned}
$$

G. Kendala Kapasitas Jumlah Produksi

Pabrik memiliki keterbatasan dalam jumlah baja tulangan yang diproduksi setiap bulannya yaitu 25.000 ton. Penulisan dalam bentuk persamaan : 
Keterangan : $\mathrm{A}_{\mathrm{t}}-\mathrm{R}_{\mathrm{t}}$ : jumlah baja tulangan yang harus diproduksi setiap bulannya.

Contoh penulisan dalam bentuk persamaan matematis :

1. $\mathrm{A}_{1}+\mathrm{B}_{1}+\mathrm{C}_{1}+\mathrm{D}_{1}+\mathrm{E}_{1}+\mathrm{F}_{1}+\mathrm{G}_{1}+\mathrm{H}_{1}+\mathrm{I}_{1}+\mathrm{J}_{1}+\mathrm{K}_{1}+\mathrm{L}_{1}+\mathrm{M}_{1}+\mathrm{N}_{1}+\mathrm{O}_{1}+\mathrm{P}_{1}+\mathrm{Q}_{1}+\mathrm{R}_{1} \leq 25.000$

H. Kendala Ketersediaan Baja Tulangan di Gudang

Ketersediaan barang di gudang dapat mencegah pabrik untuk melakukan produksi dengan jumlah yang berlebihan dengan menggunakan produk yang tersisa dari produksi bulan sebelumnya. Penulisan dalam bentuk persamaan :

$$
\mathrm{UA}_{0}-\mathrm{R}_{0}=\mathrm{yb} \text { (ton) }
$$

Keterangan : yb : sisa persediaan barang di gudang pada bulan sebelumnya

Contoh penulisan dalam bentuk persamaan matematis :

1. $\mathrm{UA}_{0}=152,31008$

\section{Hasil Jumlah Produksi dengan 3 Shift}

Dari hasil optimasi dengan menggunakan program Lingo didapatkan perencanaan produksi yang tepat dan sesuai target perusahaan. Hasil perencanaan produksi dengan menggunakan 3 shift menunjukkan bahwa semua permintaan untuk 18 jenis tulangan dapat terpenuhi dengan baik dan terdapat pengurangan jam kerja yang dibutuhkan untuk melakukan proses produksi baja tulangan tersebut. Untuk produksi pada awal periode peramalan (Mei 2018), jumlah produksi dapat dikurangi karena ketersediaan baja tulangan yang bervariasi dan jumlah persediaannya yang sangat banyak. Total biaya yang diperlukan untuk melakukan proses produksi selama 1 tahun perencanaan yang meliputi produksi baja tulangan, biaya penyimpanan dan biaya jam kerja adalah sebesar Rp 1.301.490.788.783,--

\section{Hasil Jumlah Produksi Skenario 1 dengan 2 Shift}

Penelitian lanjut dengan menggunakan 2 shift sebagai jam kerja dengan asumsi jam kerja lembur dapat bertambah jika ada permintaan yang belum terpenuhi. Hasil perencanaan produksi dengan menggunakan 2 shift ini menunjukkan bahwa semua permintaan tetap dapat terpenuhi, walaupun terdapat pertambahan jam kerja lembur di akhir periode (April 2019). Untuk persediaan di gudang juga mengalami pertambahan jika dibandingkan dengan menggunakan 3 shift karena mendahulukan produksi pada bulan sebelumnya untuk memenuhi permintaan beberapa bulan ke depan. Total biaya yang diperlukan untuk melakukan proses produksi selama 1 tahun perencanaan dengan menggunakan 2 shift ini adalah sebesar Rp 1.302.327.073.616,--

\section{Hasil Jumlah Produksi Skenario 2 dengan 2 Shift Terbatas}

Penelitian lanjut pada skenario 2 ini menggunakan 2 shift sebagai jam kerja dengan asumsi jam kerja lembur hanya setengah jam untuk setiap shift. Hasil perencanaan produksi yang didapat jika menggunakan skenario 2 dengan 2 shift terbatas menunjukkan bahwa terdapat salah satu jenis tulangan yang tidak dapat diproduksi. Hal ini dikarenakan jam kerja yang kurang dan berpengaruh terhadap pemenuhan permintaan pada bulan - bulan selanjutnya.

Adapun contoh hasil jumlah produksi dengan 3 shift dapat dilihat pada tabel 4, tabel 5 dan tabel 6 di bawah ini.

Tabel 4. Hasil Optimasi Produksi dengan 3 Shift

\begin{tabular}{|c|c|c|c|c|c|c|c|}
\hline \multirow{2}{*}{ No } & \multirow{2}{*}{ Material } & \multicolumn{6}{|c|}{ Hasil Dptimasi Produksi 2018 - 2019 [kg] } \\
\hline & & Mei & Juni & Juli & Agustus & September & Dktober \\
\hline 1 & E-TP24-1212PT-00 & 0.000 & 0.000 & 0.000 & 0.000 & 0.000 & $30,800.910$ \\
\hline 2 & E-TS40-1012TL-00 & $1,748,734.000$ & $1,609,028.000$ & $1,811,757.000$ & $2,080,524.000$ & $1,859,161.000$ & $2,148,106.000$ \\
\hline 3 & E-TS40-1312TL-00 & $627,587.000$ & $2,400,310.000$ & $2,477,996.000$ & $2,359,417.000$ & $2,033,445.000$ & $3,261,111.000$ \\
\hline 4 & E-TS40-1612TL-00 & 0.000 & $982,550.000$ & $2,051,002.000$ & $1,724,503.000$ & $1,958,435.000$ & $2,202,652.000$ \\
\hline 5 & E-TS40-1912TL-00 & 0.000 & $618,053.300$ & $223,177.500$ & $1,620,038.000$ & $1,295,701.000$ & $1,798,822.000$ \\
\hline 6 & E-TS40-2212TL-00 & 0.000 & $508,674.400$ & $1,391,905.000$ & $1,454,933.000$ & $2,137,468.000$ & $1,212,538.000$ \\
\hline 7 & E-TS40-2512TL-00 & 0.000 & 0.000 & $190,749.700$ & $1,462,279.000$ & $3,834,369.000$ & $2,331,840.000$ \\
\hline 8 & E-TS40-2912TL-00 & 0.000 & 0.000 & 0.000 & 0.000 & $53,869.860$ & $151,982.600$ \\
\hline 9 & E-TS40-3212TL-00 & 0.000 & 0.000 & 0.000 & $328,615.800$ & $2,077,287.000$ & $3,493,624.000$ \\
\hline 10 & E-TS40-4012TL-00 & 0.000 & 0.000 & 0.000 & 0.000 & 0.000 & 0.000 \\
\hline 11 & E-TS50-1012TL-00 & 0.000 & $12,343.760$ & $438,239.500$ & $362,914.100$ & $320,445.000$ & $347,360.000$ \\
\hline 12 & E-TS50-1312TL-00 & 0.000 & 0.000 & 0.000 & $439,904.200$ & $291,729.300$ & $308,421.100$ \\
\hline 13 & E-TS50-1612TL-00 & 0.000 & 0.000 & 0.000 & 0.000 & 0.000 & $227,551.200$ \\
\hline 14 & E-TS50-1912TL-00 & 0.000 & 0.000 & 0.000 & 0.000 & 0.000 & $67,362.860$ \\
\hline 15 & E-TS50-2212TL-00 & 0.000 & 0.000 & 0.000 & 0.000 & 0.000 & $348,410.900$ \\
\hline 16 & E-TS50-2512TL-00 & 0.000 & 0.000 & 0.000 & $80,869.490$ & $104,261.400$ & $138,593.300$ \\
\hline 17 & E-TS50-2912TL-00 & $18,765.550$ & $126,179.700$ & 0.000 & 0.000 & $128,975.900$ & 0.000 \\
\hline 18 & E-TS50-3212TL-00 & 0.000 & $441,665.100$ & $1,213,576.000$ & 0.000 & 0.000 & $565,472.000$ \\
\hline & Total Produksi & $2,395,086.550$ & $6,698,804.260$ & $9,798,402.700$ & $11,913,997.590$ & $16,095,147.460$ & $18,634,647.870$ \\
\hline
\end{tabular}


Jurnal Mitra Teknik Sipil

Vol. 1, No. 1, Agustus 2018: hlm 29-38

Tabel 4. Hasil Optimasi Produksi dengan 3 Shift (Lanjutan)

\begin{tabular}{|c|c|c|c|c|c|c|c|}
\hline \multirow{2}{*}{ No } & \multirow{2}{*}{ Material } & \multicolumn{6}{|c|}{ Hasil Optimasi Gudang 2018 - 2019 (kg) } \\
\cline { 3 - 8 } & & Mei & Juni & Juli & Agustus & September & Oktober \\
\hline 1 & E-TP24-1212PT-00 & $103,277.100$ & $97,442.580$ & $91,777.030$ & $83,643.880$ & $30,333.500$ & $14,107.940$ \\
\hline 2 & E-TS40-1012TL-00 & $150,000.000$ & $150,000.000$ & $150,000.000$ & $150,000.000$ & $150,000.000$ & $150,000.000$ \\
\hline 3 & E-TS40-1312TL-00 & $150,000.000$ & $150,000.000$ & $150,000.000$ & $150,000.000$ & $150,000.000$ & $150,000.000$ \\
\hline 4 & E-TS40-1612TL-00 & $288,127.000$ & $150,000.000$ & $150,000.000$ & $150,000.000$ & $150,000.000$ & $150,000.000$ \\
\hline 5 & E-TS40-1912TL-00 & $926,081.700$ & $150,000.000$ & $86,117.880$ & $150,000.000$ & $150,000.000$ & $150,000.000$ \\
\hline 6 & E-TS40-2212TL-00 & $875,030.600$ & $150,000.000$ & $150,000.000$ & $150,000.000$ & $150,000.000$ & $150,000.000$ \\
\hline 7 & E-TS40-2512TL-00 & $1,870,817.000$ & $1,076,284.000$ & $150,000.000$ & $150,000.000$ & $150,000.000$ & $150,000.000$ \\
\hline 8 & E-TS40-2912TL-00 & $1,846,901.000$ & $1,592,310.000$ & $1,397,383.000$ & $614,357.000$ & $150,000.000$ & $69,688.290$ \\
\hline 9 & E-TS40-3212TL-00 & $3,112,876.000$ & $2,062,511.000$ & $1,583,994.000$ & $150,000.000$ & $150,000.000$ & $150,000.000$ \\
\hline 10 & E-TS40-4012TL-00 & $404,571.300$ & $404,571.300$ & $404,571.300$ & $404,571.300$ & $404,571.300$ & $374,369.100$ \\
\hline 11 & E-TS50-1012TL-00 & $204,587.500$ & $50,061.060$ & $112,684.700$ & $109,753.600$ & $99,276.600$ & $103,070.000$ \\
\hline 12 & E-TS50-1312TL-00 & $1,109,584.000$ & $873,223.800$ & $254,741.900$ & $150,000.000$ & $101,937.500$ & $94,698.150$ \\
\hline 13 & E-TS50-1612TL-00 & $837,343.600$ & $691,511.900$ & $380,133.100$ & $140,079.000$ & $84,892.850$ & $72,102.480$ \\
\hline 14 & E-TS50-1912TL-00 & $227,933.200$ & $191,207.200$ & $159,102.000$ & $100,518.600$ & $30,892.770$ & $22,674.380$ \\
\hline 15 & E-TS50-2212TL-00 & $572,455.300$ & $533,579.600$ & $427,379.400$ & $263,366.500$ & $151,645.700$ & $115,397.700$ \\
\hline 16 & E-TS50-2512TL-00 & $355,340.800$ & $230,748.100$ & $96,686.200$ & $40,974.390$ & $33,515.940$ & $39,717.510$ \\
\hline 17 & E-TS50-2912TL-00 & $8,369.130$ & $31,049.730$ & $31,049.730$ & $18,569.660$ & $34,048.980$ & $34,048.980$ \\
\hline 18 & E-TS50-3212TL-00 & $492,225.300$ & $150,000.000$ & $150,000.000$ & $147,491.500$ & $138,174.200$ & $150,000.000$ \\
\hline \multicolumn{2}{|c|}{ Total Penyimpanan } & $13,535,520.530$ & $8,734,500.270$ & $5,925,620.240$ & $3,123,325.430$ & $2,309,289.340$ & $2,139,874.530$ \\
\hline
\end{tabular}

Tabel 5. Hasil Optimasi Gudang dengan 3 Shift

\begin{tabular}{|c|c|c|c|c|c|c|c|}
\hline \multirow{2}{*}{ No } & \multirow{2}{*}{ Material } & \multicolumn{6}{|c|}{ Hasil Dptimasi Produksi 2018 - 2019 [kg] } \\
\hline & & November & Desember & Januari & Februari & Maret & April \\
\hline 1 & E-TP24-1212PT-00 & 0.000 & 0.000 & $7,045.200$ & $64,033.850$ & $43,209.420$ & 0.000 \\
\hline 2 & E-TS40-1012TL-00 & $2,382,931.000$ & $1,119,610.000$ & $1,231,246.000$ & $1,376,289.000$ & $1,192,230.000$ & $1,328,522.000$ \\
\hline 3 & E-TS40-1312TL-00 & $2,432,469.000$ & $2,511,106.000$ & $2,390,859.000$ & $2,060,471.000$ & $3,304,339.000$ & $2,464,627.000$ \\
\hline 4 & E-TS40-1612TL-00 & $2,356,086.000$ & $1,201,334.000$ & $2,196,868.000$ & $1,845,712.000$ & $2,094,493.000$ & $2,353,924.000$ \\
\hline 5 & E-TS40-1912TL-00 & $1,613,238.000$ & $280,038.800$ & $1,848,496.000$ & $1,481,787.000$ & $2,049,951.000$ & $1,832,341.000$ \\
\hline 6 & E-TS40-2212TL-00 & $1,367,921.000$ & $1,429,755.000$ & $2,100,317.000$ & $1,191,371.000$ & $1,343,938.000$ & $1,404,577.000$ \\
\hline 7 & E-TS40-2512TL-00 & $1,844,358.000$ & $938,326.900$ & $1,313,274.000$ & $1,711,864.000$ & $4,470,726.000$ & $2,708,419.000$ \\
\hline 8 & E-TS40-2912TL-00 & $431,948.200$ & $256,099.000$ & $1,181,946.000$ & $722,314.100$ & $262,225.600$ & $572,028.700$ \\
\hline 9 & E-TS40-3212TL-00 & $2,028,749.000$ & $854,244.100$ & $2,958.758 .000$ & $3,318,516.000$ & $5,358,310.000$ & $3,007,133.000$ \\
\hline 10 & E-TS40-4012TL-00 & 0.000 & 0.000 & 0.000 & 0.000 & 0.000 & 0.000 \\
\hline 11 & E-TS50-1012TL-00 & $351,589.000$ & $758,320.700$ & $644,580.400$ & $951,608.600$ & $142,289.100$ & $532,605.200$ \\
\hline 12 & E-TS50-1312TL-00 & $340,299.000$ & $905,461.600$ & 738.772 .200 & $438,696.700$ & $402,517.300$ & $438,486.600$ \\
\hline 13 & E-TS50-1612TL-00 & $558,448.700$ & $319,307.200$ & 0.000 & $407,294.200$ & $708,244.500$ & $467,567.700$ \\
\hline 14 & E-TS50-1912TL-00 & $18,036.070$ & $38,468.680$ & 30.795 .950 & 66.693 .420 & $73,121.010$ & $77,561.410$ \\
\hline 15 & E-TS50-2212TL-00 & $258,806.600$ & $162,555.400$ & $408,216.100$ & $468,309.300$ & $204,793.800$ & $964,828.500$ \\
\hline 16 & E-TS50-2512TL-00 & $482,331.400$ & $146,898.000$ & $214,893.700$ & $208,673.100$ & 153.659 .200 & $200,248.700$ \\
\hline 17 & E-TS50-2912TL-00 & 0.000 & 61.485 .740 & 0.000 & 0.000 & $58,246.550$ & 0.000 \\
\hline 18 & E-TS50-3212TL-00 & $828,876.200$ & 0.000 & 0.000 & $277,874.800$ & $480,408.400$ & 0.000 \\
\hline & Total Produksi & $17,296,087.170$ & $10,983,011.120$ & $17,266,067.550$ & $16,591,508.070$ & $22,342,701,880$ & $18,352,869.810$ \\
\hline
\end{tabular}

Tabel 5. Hasil Optimasi Gudang dengan 3 Shift (Lanjutan)

\begin{tabular}{|c|c|c|c|c|c|c|c|}
\hline \multirow{2}{*}{ No } & \multirow{2}{*}{ Material } & \multicolumn{7}{|c|}{ Hasil Optimasi Gudang 2018 - 2019 (kg) } \\
\cline { 3 - 8 } & & November & Desember & Januari & Februari & Maret & April \\
\hline 1 & E-TP24-1212PT-00 & $8,514.190$ & $3,084.340$ & $2,337.590$ & $15,316.490$ & $13,505.980$ & $8,152.960$ \\
\hline 2 & E-TS40-1012TL-00 & $150,000.000$ & $150,000.000$ & $150,000.000$ & $150,000.000$ & $150,000.000$ & $150,000.000$ \\
\hline 3 & E-TS40-1312TL-00 & $150,000.000$ & $150,000.000$ & $150,000.000$ & $150,000.000$ & $150,000.000$ & $150,000.000$ \\
\hline 4 & E-TS40-1612TL-00 & $150,000.000$ & $150,000.000$ & $150,000.000$ & $150,000.000$ & $150,000.000$ & $150,000.000$ \\
\hline 5 & E-TS40-1912TL-00 & $150,000.000$ & $99,239.730$ & $150,000.000$ & $150,000.000$ & $150,000.000$ & $150,000.000$ \\
\hline 6 & E-TS40-2212TL-00 & $150,000.000$ & $150,000.000$ & $150,000.000$ & $150,000.000$ & $150,000.000$ & $150,000.000$ \\
\hline 7 & E-TS40-2512TL-00 & $150,000.000$ & $150,000.000$ & $150,000.000$ & $150,000.000$ & $150,000.000$ & $150,000.000$ \\
\hline 8 & E-TS40-2912TL-00 & $115,762.300$ & $85,814.130$ & $150,000.000$ & $150,000.000$ & $95,128.980$ & $150,000.000$ \\
\hline 9 & E-TS40-3212TL-00 & $150,000.000$ & $150,000.000$ & $150,000.000$ & $150,000.000$ & $150,000.000$ & $150,000.000$ \\
\hline 10 & E-TS40-4012TL-00 & $341,659.900$ & $341,659.900$ & $341,659.900$ & $341,659.900$ & $341,659.900$ & $311,457.700$ \\
\hline 11 & E-TS50-1012TL-00 & $104,921.300$ & $150,000.000$ & $150,000.000$ & $551,898.000$ & $150,000.000$ & $150,000.000$ \\
\hline 12 & E-TS50-1312TL-00 & $100,384.000$ & $150,000.000$ & $150,000.000$ & $135,853.100$ & $124,239.300$ & $129,859.800$ \\
\hline 13 & E-TS50-1612TL-00 & $145,511.800$ & $107,265.900$ & $28,012.920$ & $100,455.500$ & $150,000.000$ & $142,515.600$ \\
\hline 14 & E-TS50-1912TL-00 & $9,394.720$ & $11,045.400$ & $9,655.700$ & $17,619.030$ & $20,940.010$ & $22,731.100$ \\
\hline 15 & E-TS50-2212TL-00 & $86,354.820$ & $57,440.820$ & $107,459.300$ & $132,869.700$ & $77,922.330$ & $240,634.800$ \\
\hline 16 & E-TS50-2512TL-00 & $120,472.800$ & $61,700.970$ & $63,829.530$ & $62,885.220$ & $49,971.780$ & $57,743.190$ \\
\hline 17 & E-TS50-2912TL-00 & $17,017.840$ & $18,116.210$ & $18,116.210$ & $11,672.790$ & $16,135.230$ & $16,135.230$ \\
\hline 18 & E-TS50-3212TL-00 & $150,000.000$ & $148,355.100$ & $142,547.700$ & $97,020.570$ & $133,252.800$ & $132,471.600$ \\
\hline \multicolumn{2}{|c|}{ Total Penyimpanan } & $2,249,993.670$ & $2,133,722.500$ & $2,213,618.850$ & $2,667,250.300$ & $2,222,756.310$ & $2,411,701.980$ \\
\hline
\end{tabular}


Tabel 6. Hasil Optimasi Jam Kerja dengan 3 Shift

\begin{tabular}{|c|c|c|c|}
\hline No & Bulan & Jam Kerja Reguler (kr) & Jam Kerja Lembur (k) \\
\hline 1 & Mei 2018 & 61 & 0 \\
\hline 2 & Juni 2018 & 159 & 0 \\
\hline 3 & Juli 2018 & 231 & 0 \\
\hline 4 & Agustus 2018 & 280 & 0 \\
\hline 5 & September 2018 & 364 & 0 \\
\hline 6 & Oktober 2018 & 423 & 0 \\
\hline 7 & November 2018 & 398 & 0 \\
\hline 8 & Desember 2018 & 255 & 0 \\
\hline 9 & Januari 2019 & 389 & 0 \\
\hline 10 & Februari 2019 & 376 & 0 \\
\hline 11 & Maret 2019 & 462 & 33 \\
\hline 12 & April 2019 & 416 & 0 \\
\hline \multicolumn{2}{|c|}{ Total } & 3814 & 33 \\
\hline
\end{tabular}

\section{KESIMPULAN}

Kesimpulan yang dapat diambil dari penelitian ini adalah sebagai berikut:

1. Ketersediaan baja tulangan di gudang pada bulan sebelumnya memiliki jumlah yang cukup bervariasi dan sangat membantu dalam kegiatan proses produksi, sehingga pabrik dapat mengurangi jumlah produksi pada awal periode peramalan (Mei 2018).

2. Hasil produksi yang berbeda akibat perbedaan shift jam kerja mempengaruhi jumlah penyimpanan baja tulangan di gudang. Total biaya penyimpanan baja tulangan dengan 3 shift selama 1 tahun sebesar Rp 298.003.044,- dan total biaya penyimpanan jika menggunakan skenario 1 dengan 2 shift sebesar Rp 1.130.152.108,--

3. Hasil penelitian dengan menggunakan perbedaan shift jam kerja menunjukkan bahwa untuk melakukan produksi dengan 3 shift selama 1 tahun membutuhkan total biaya sebesar Rp 1.301.490.788.783,-. Jika menggunakan skenario 1 dengan 2 shift, maka akan membutuhkan biaya sebesar Rp 1.302.327.073.616,- Untuk skenario 2 dengan 2 shift terbatas, produksi tidak dapat terpenuhi karena jam kerja yang kurang. Jadi jam kerja dan kecepatan produksi sangat berpengaruh dalam menghasilkan baja tulangan yang baik.

\section{DAFTAR PUSTAKA}

Badan Standarisasi Nasional. (2014). SNI 2052:2014 Baja Tulangan Beton. Jakarta: Badan Standarisasi Nasional. Chatterjee, Dipak. (2005). Linear Programming and Game Theory. New Delhi : Phi Learning Pvt. Ltd.

Coyle, John J., C. John Langley, Jr., Brian J. Gibson, Robert A. Novack and Edward J. Bardi. (2009). Supply Chain Management : A Logistics Perspective. $8^{\text {th }}$ edition. Mason : Cengage Learning.

Gaspersz, Vincent. (2004). Production Planning and Inventory Control. Jakarta : PT Gramedia Pustaka Umum.

Herjanto, Eddy. (2008). Manajemen Operasi. Edisi 3. Jakarta : Grasindo.

Hutajulu, O.P. (2010). Kajian Peramalan Permintaan dan Perencanaan Optimasi Produksi Semen pada Plant 11 PT Indocement Tunggal Prakarsa Tbk. Bogor : Institut Pertanian Bogor.

Indonesian Iron and Steel Industry Association. "Indonesia Steel Industries : Development \& Opportunities." Organisation for Economic Co-operation and Development. 29 September 2017. (On-Line). 9 Februari 2018. https://www.oecd.org/industry/ind/Item_9_5_Indonesia.pdf

Prasetya, Hery dan Fitri Lukiastuti. (2009). Manajemen Operasi. Yogyakarta : Medpress.

Shao, Ju-ping, Dong Shao-hua, Hu Bo dan Liang Jian. (2007). "Theory and Method of Production Logistics Plan Optimizing for An Iron and Steel Enterprise." International Conference on Transportation Engineering. China : Southwest Jiaotong University.

Sharma, J.K. (2007). Business Statistics. $2^{\text {nd }}$ edition. New Delhi : Dorling Kindersley (India) Pvt. Ltd. 